\title{
Determinants of Investment Opportunity Set (Degree of Internationalization and Macroeconomic Variables)
}

\author{
Cynthia A. Utama* and Meiti Sulistika
}

Faculty of Economics, University of Indonesia, Indonesia

\begin{abstract}
The aim of this study is to investigate the influence of internal factors (i.e. the degree of internationalization, profitability, firm size, and financial leverage) and external factors (i.e. GNP growth and the inflation rate) on firms' growth opportunities or their Investment Opportunity Set (IOS). The IOS is measured by the market-to-book assets ratio. The result shows that profitability and firms' size have a positive impact on the IOS whereas the degree of internationalization and financial leverage has a negative influence on the IOS. Finally, the IOS is positively affected by GNP growth while the inflation rate has a negative impact on IOS.
\end{abstract}

Abstrak: Tujuan dari penelitian ini adalah untuk mengetahui pengaruh faktor internal (yaitu tingkat internasionalisasi, profitabilitas, ukuran perusahaan, dan leverage keuangan) dan faktor eksternal (yaitu pertumbuhan GNP dan tingkat inflasi) pada peluang pertumbuhan perusahaan atau set peluang investasi (IOS). IOS diukur dengan rasio aset market-to-book. Hasil penelitian menunjukkan bahwa profitabilitas dan ukuran perusahaan 'memiliki dampak positif pada IOS sedangkan tingkat internasionalisasi dan leverage keuangan memiliki pengaruh negatif pada IOS. Akhirnya, IOS positif dipengaruhi oleh pertumbuhan GNP sementara tingkat inflasi memiliki dampak negatif pada IOS.

Keywords: degree of internationalization; firm size; gross national product; inflation rate; investment opportunity set; leverage; market to book ratio; profitability

JEL classification: E43; E44; G31; G32

* Corresponding author's e-mail: cynthiautama@gmail.com, cynthiautama@yahoo.com, cynthia.afriani@ui.ac.id 


\section{Introduction}

A firm's value is a function of its existing assets (assets-in-place) and growth opportunities (Myers 1977; AlNajjar and RiahiBelkaoui 2001; Kallapur and Trombley 2001). Kester (1984) corroborated that a firm's investment choices include firm growth opportunities that determine the firm's real value and profit potential. Mason and Merton (1985) mentioned that a high growth company is a company which has the capacity to carry out investment activities in the form of the purchase of assets, such as machines, that support the production, the introduction of new products, the acquisition of other companies, and other capital expenditure associated with the maintenance and replacement of the assets of the company. Vogt (1997) mentioned that markets will react positively to firms which have a positive net present value of growth opportunities.

As mentioned above, the Investment Opportunity Set (henceforth, IOS) represents investment options held by companies today, thus the IOS is very important in determining how the company grows in the future. Therefore, determinants of IOS will affect how investors appraise the company (Kallapur and Trombley 2001).

AlNajjar and Riahi-Belkaoui (2001) found that a firm's internal factors (i.e. the degree of internationalization, profitability, leverage, and firm size) determine the IOS, while Riahi-Belkaoui (2002) stated that internal factors and external factors (i.e. GNP and inflation) affect the IOS.

Xiao et al. (2013) stated that previous studies investigating the influence of internationalization on firms' performance showed contradictory and inconsistent results. Further, those empirical studies focused on multinational corporations in developed countries.

On the other hand, Indonesian firms operating in emerging economies tend to lack experience, have fewer resources, and are newly internationalized, relative to multinational corporations in developed countries. Further, international trade in Indonesia is a significant proportion of the Gross Domestic Product (GDP) as shown below.

Indonesia's GDP per capita has risen almost 5 fold in the past forty years (Figure 1). Trade has played an important role in this remarkable achievement. In the past 25 years, i.e. until 2010 trade, as a share of GDP, increased significantly in Indonesia, in part due to the country's outward oriented development strategy. And while the deep global trade contraction in 2009 is apparent, more recent data suggests that trade has increased to levels closer to trend (OECD 2012).

As trade increases in proportion to GDP, then this also brings an increase in foreign direct investments. OECD (2012) stated that:

Inward stocks of Foreign Direct Investment (FDI) in Indonesia have been increasing steadily since 2003 and stood at $17 \%$ of GDP in 2010. This upward trend persisted in spite of the global economic crisis of 200809; in fact, inward FDI stocks as a share of GDP reached their highest point (20\%) in the last 7 years in 2009, the worst year of the global economic crisis. This reflects Indonesia's attractiveness as an investment destination both in terms of its large domestic market as well as its location as a production platform to serve other Asian markets. However, Indonesia's FDI performance lags most of the other ASEAN economies, suggesting that there is significant scope to further boost investment. 
Figure 1. Evolution of GDP per Capita and Trade as A Share of GDP in Indonesia

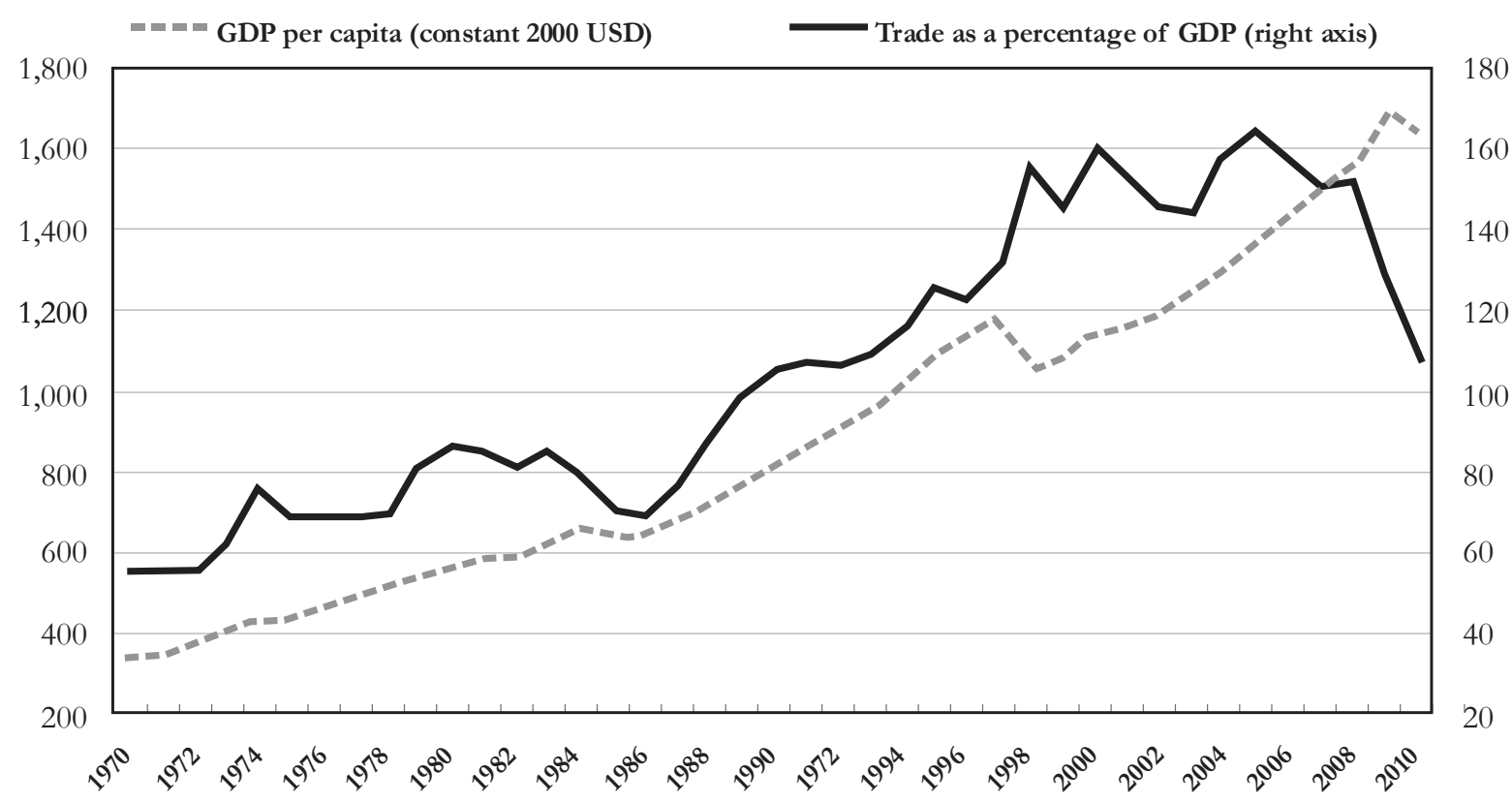

Considering that trade has a significant role in the economy, then a study examining whether internationalization has a significant impact on firms' investment opportunities warrants further research. It is also intriguing to investigate the influence of internationalization of firms in underdeveloped countries like Indonesia.

As far as we know, the extant literature that investigates the influence of internal factors and external factors simultaneously on IOS is very rare. In Indonesia, Hasibuan (2007) and Tumpal and Natalia (2007) investigated the influence of internal factors on the company IOS without considering the impact of external factors or macroeconomic variables on IOS. Ratnawati (2007) examined the impact of inflation on IOS but did not examine the influence of internal factors on IOS.

Further, the extant literature that considers the impact of the degree of internationalization on IOS is quite rare, though currently many companies export their products abroad. Delios and Henisz (2000) stated that internationalization requires the development of knowledge and capabilities regarding international market conditions, and that the companies also faced uncertainty and constraints related to the environment at the international level. International trade regulations in the country where the company is expanding its market will limit the degree of internationalization of the firm (Hill 2007). This condition may restrain the firms' growth opportunities. AlNajjar and Riahi-Belkaoui (2001), Riahi-Belkaoui (2002), and Hasibuan (2007) found a negative relationship between the level of internationalization and IOS.

Based on the previous explanations, the objectives of this study were to investigate: (1) the influence of profitability, firm size, degree of internationalization, and leverage on IOS; (2) the influence of external factors, i.e. GNP growth and inflation rate on IOS. 
The remainder of the paper is organized as follows. Section 2 reviews the literature and hypotheses development. Section 3 describes the data and methodology. Section 4 describes the empirical results and section 5 concludes the paper.

\section{Hypotheses Development}

Profitability shows a company's ability to earn profit. A higher profitability allows the firm to sustain its existence in their chosen industry. The level of profitability represents how profitable a business is (Keown et al. 2002). So, a firm's profitability reflects its performance to potential investors (Savitri 2009). Further, the greater the firm's profitability is, the bigger the possibility of retained earnings for investment purposes. Firms' Investment Opportunity Sets are positively influenced by profitability. Bodie et al. (2009) argued that projects with high profitability (i.e. higher return on equity or ROE) increased a firm's growth opportunities if the firm could invest its earnings into projects where the ROE exceeded the cost of capital. Consequently, firms with good investment opportunities tend to increase their retained earnings or plow back ratio (i.e. the ratio of retained earnings-to-net income). Further, Bodie et al. (2009) elaborated on the relationship between the Return on Equity (ROE), the Price to Earnings ratio ( $\mathrm{P} / \mathrm{E}$ ratio), and the Price to Book Value (PBV or P/

$\mathrm{B})$ as proxies of the IOS or growth opportunities as shown below

$$
\frac{P}{E}=\frac{P / B}{R O E}
$$

According to Bodie et al. (2009), Wall Street distinguishes between "good firms" and "good investments." A good firm may be highly profitable, with a correspondingly high ROE. But if its stock price is bid up to a level commensurate with this ROE, its $\mathrm{P} / \mathrm{B}$ ratio will also be high, and the stock price may be a relatively large multiple of earnings, thus reducing its attractiveness as an investment. The high ROE of the firm does not by itself imply that the stock is a good investment. Conversely, troubled firms with low ROEs can be good investments if their prices are low enough. Thus, we conclude that there is a positive relationship between profitability and IOS (Riahi-Belkaoui 2002).

\section{$H_{1}$ : Profitability has a positive influence on the In- vestment Opportunity Set.}

A larger firm size usually means it has larger assets that can be used for investment, and makes it easier for the firm to compete and dominate the market. Gaver and Gaver (1993) found that the greater the firm's size and the more established the company was, it would have higher investment opportunities compared to those of a smaller company. In addition, a larger size firm has lower asymmetric information and a higher reputation, so the company has easier access to external financing. Large and more established firms tend to be more active in increasing the value of their investments in various ways, such as product differentiation to create barriers to entry, economies of scale, and patents (Chung and Charoenwong 1991). AlNajjar and RiahiBelkaoui (2001) also corroborated that a firm's size has a positive impact on its IOS. They argued that small companies often face limitations or difficulties in determining the choice and execution of new projects, or difficulties in restructuring existing assets, while large companies tend to dominate the market position in their industry. In other words, a greater firm size results in greater investment opportunities. 
Dhanaraj and Bearnish (2003) also stated that larger firms have a larger quantum of resources and availability of managerial resources. Bloodgood et al. (1996) also showed that larger firms have the capability to hire more skilled managers than smaller firms. Therefore, larger firms have more capacity to fund their growth opportunities than smaller firms.

\section{$\mathrm{H}_{2}$ : Firm size has a positive effect on IOS.}

Sapienza et al. (2006) argued that a company that has entered the international market needs to adapt to the environment of the country where the company is expanding its market. Singla and George (2013) also support the fact that internationalization causes additional costs of learning about the foreign culture and markets, and firms when they first start in a foreign market might suffer from poor product image. Hope et al. (2011) also mentioned that:

Other costs include those in manufacturing and selling abroad which are needed to modify the production process and marketing strategy to adapt the product to local conditions. Further, a firm incurs costs associated with staffing, and setting up an internal management system and an external business network.

Delios and Henisz (2000) stated that in addition to requiring the development of knowledge and capabilities regarding international market conditions, the company also faced uncertainty and constraints related to the environment at the international level. International trade regulations in the country where the company is expanding its market will limit the degree of internationalization of the firm (Hill 2007). This condition will hinder the firm's investment growth opportunities. Consistent with this view, AlNajjar and Riahi-Belkaoui (2001), Riahi-Belkaoui (2002), and Hasibuan (2007) found a negative relationship between the level of internationalization and IOS.

$H_{3}:$ The level of internationalization negatively affects the IOS.

Higher financial leveraged firms will experience a higher risk of default due to their inability to pay the interest and principal of their debt (Angeline 2007). Likewise, the interest payments and principal of debt may increase the potential loss of investment because the interest and principal payments can be higher than the return on investment. In addition, using leverage in the firm's capital structure also limits the investment decisions due to the boundaries in the debt covenants (negative covenants), where the lender determines certain restrictions to ensure repayment of the principal and interest. Francis et al. (2013) showed that financial leverage indicates a firm's riskiness and higher leverage impacts on its access to external financing. Thus, firms with a higher leverage have a higher financial risk than those with a lower leverage, and they tend to reduce their business risk through a lower Investment Opportunity Set. Therefore, leverage has a negative influence on IOS (Gaver and Gaver 1993; Gul 1999; AlNajjar and Riahi-Belkaoui 2001).

\section{$H_{4}$ : Leverage has a negative effect on IOS.}

The Gross National Product (henceforth, GNP) measures the overall economic strength of a country and is an indicator of economic prosperity. Major changes in GNP (i.e. GNP growth) provide a signal of a country's economic strength and consequently, act as an indicator for companies to make an investment decision. A positive trend in GNP growth will create a favorable cli- 
mate for investment. Francis et al. (2013) also corroborate that higher GDP enhances the growth of financial markets and consequently provides better investment opportunities. Lakonishok et al. (1994) showed that economic growth (i.e. growth in real GDP) has a positive influence on the IOS (i.e. price to book value). Countries with lower economic growth are assumed to have a bad economic outlook and consequently, these countries' firms trade at discount or have a lower price to book value. Therefore, the annual change in GNP is expected to have a positive impact on IOS (Riahi- Belkaoui 2002).

$H_{5}$ : The annual growth in GNP has a positive influence on the Investment Opportunity Set.

Unanticipated increases in inflation will affect companies' wages and the Cost Of Goods Sold (COGS), total asset value, and the market price of the company's product. Unanticipated inflation creates uncertainty about the future economic situation (Sukirno 2004). This situation decreases a company's motivation to develop its economic activities. A firm's investments are highly dependent on changes in the inflation rate, because the inflation rate determines nominal interest rates and consequently affects the costs of capital for the firm's investments. High rates of inflation will increase interest rates, which in turn will reduce investment. As mentioned above, Lakonishok et al. (1994) argued that lower economic growth, indicated by higher inflation, yields a lower IOS (i.e. price to book value). This argument is supported by Bodie et al. (2002) who showed that the market value of a firm is affected by the cost of capital in the constant dividend growth model provided below:

$$
P=\frac{D 1}{k-g}
$$

where $P$ is the market price, while $k$ and $g$ show the cost of capital and expected growth consecutively. Hence, unanticipated increases in inflation produce higher costs of capital and given the ceteris paribus of other variables, market price and also price to book value will be reduced. Thus, the inflation rate has a negative effect on the IOS (Ratnawati 2007).

\section{$H_{6}$ : Inflation rate negatively affects the Investment Opportunity Set.}

A firm's age indicates its ability to continue to carry out its business and shows a level of learning curve or firm experience (Febriana 2004). The age of a firm also prevents potential bias towards newly diversified firms in the international market area (Kim et al. 1989). Previous studies showed that a firm's growth or investment opportunities had a positive correlation with the firm's age (Das 1995; Heshmati 2001; Ermini 2008; Teruel-Carrizosa 2010). Growth opportunity can be represented by the $\mathrm{R} \& \mathrm{D}$-to-assets ratio (Brown and Peterson 2009) or innovational performance (Yildiz et al. 2013). Besides, an established company tends to increase its public confidence in the company so that it will increase its growth opportunities.

\section{$H_{7}$ : The Investment Opportunity Set is positively influenced by a firm's age. \\ In addition, the extant literature shows} that any negative influence of internationalization is affected by the firm's size and age. Firms that are characterized by their small size and young age are assumed to be of higher risk when conducting their expansion into foreign markets because these firms tend to have a lack of resources and experience (Fernandez and Nieto 2006: Claver et al. 2008; Shrader et al. 2000). Hence, Singla and 
George (2013) concluded that the degree of risk aversion to entering a foreign market could be reduced by older and larger firms having more ability to impose patents and contracts in their international expansion.

$H_{7}$ : Firm size positively moderates the negative relationship between the IOS and the level of internationalization.

$H_{g}$ : Firms' age positively moderates the negative relationship between the IOS and the level of internationalization.

\section{Methods}

\section{Definition of Operational Variables}

This study used 6 independent variables which were expected to determine the IOS, i.e. profitability, firm size, degree of internationalization, leverage, GNP growth, and inflation rate.

\section{Investment Opportunity Set (IOS)}

One variable that is used as a proxy of IOS is the ratio of market-to-book assets (henceforth, PBV) which is the most commonly used proxy measure of investment opportunities in a company. This proxy is used to measure a company's growth prospects. PBV is the ratio of the market value of assets to the book value of assets. Generally, the PBV is greater than 1 (one), showing that a company has good investment opportunities (Smith and Watts 1992; Ho et al. 2004; AlNajjar and Riahi-Belkaouli 2001; Adam and Goyal 2007). Kallapur and Trombley (1999) and Kallapur (2001) stated that proxies of the IOC can be classified into 4 types: pricebased proxies, investment based proxies, ${ }^{1}$ variance measures, ${ }^{2}$ and composite measures. The price-based proxies are based on the assumption that growth firms will have higher market values relative to assets in place because growth prospects are at least partially impounded in the stock price. That is, a material portion of the market value of equity is accounted for by growth opportunities. Accordingly, price-based proxies are formed as a ratio incorporating a measure of the assets in place and the firm's market value. Kallapur and Trombley (1999) also showed that among the commonly used proxies, market-to-book value ratios were the most highly correlated with future growth. While, Kole (1991) and Smith and Watts (1992) used the book to market value of asset or the inversion of price to book. In other words, price to book value reflects the mix of assets in place and growth opportunities, because the book value of assets is a proxy for assets in place, and the market value of assets is a proxy for both the assets in place and growth opportunities. Therefore, this study used the ratio of market-to-book assets as a proxy representing the IOS, and it was measured as follows:

\section{Market to Book Assets= \\ (Total Assets - Total Common Equity) + (Shares Outstanding x Share Closing Price)}

Total Asstes

\section{Profitability}

Profitability is measured by the ROA, i.e. the amount of net income earned by the

${ }^{1}$ Investment-based proxies include R\&D, sales, ratio of capital expenditure to value and are based on the assumption that a high level of investment activity is positively related to the IOS.

${ }^{2}$ Variance measures include variance of returns, asset $\mathrm{b}$ and are based on the assumption that options become more valuable as the variability of returns on the underlying assets increases. 
company each year divided by the total assets of the company in the same year (RiahiBelkaoui 2002). The equation is as follows:

$$
\mathrm{ROA}=\frac{\text { Net Income }}{\text { Total Assets }}
$$

\section{Firm Size}

In line with previous empirical studies, this study employed the logarithm of total assets as a proxy of the firm's size to adjust for the large differences in size amongst companies ( Ferry and Jones 1979; AlNajjar and Riahi-Belkaoui 2001; Wibowo and Andriyani 2008).

\section{Degree of Internasionalization Level}

The degree of internationalization level is calculated by the total amount of a company's export sales expressed as a percentage of the total sales of that company (Sullivan 1994; Riahi- Belkaoui 2002; Filatotchev and Piesse 2009):

$$
\text { ESTS }=\frac{\text { Exports Sales }}{\text { Total Sales }}
$$

\section{Leverage}

A firm's leverage is proxied by the ratio of its long-term debt to total assets (AlNajjar and Riahi-Belkaoui 2001):

$$
\text { LEV }=\frac{\text { Longterm Debt }}{\text { Total Assets }}
$$

\section{Firm Age}

A firm's age in this study is shown by the total age of the assets held by the company. ${ }^{3}$ The firm's age is measured by the following equation:

$$
\text { AGE }=\frac{\text { Accumulated Depreciation }}{\text { Depreciation Expense }}
$$

\section{Sample}

The financial data used in this study were hand-collected from the annual financial statements of companies listed on the Indonesian Stock Exchange from 2000-2008. The financial statements included balance sheets, income statements, cash flows, changes in capital and this data came from the Indonesian Stock Exchange. It can be downloaded from the Indonesian Stock Exchange's web site (i.e. www.idx.co.id) or from the CD Room of the Faculty of Economics, University of Indonesia Library. Other data used in this study were the closing stock prices, which can be obtained from the Indonesian Capital Market Directory (ICMD) provided by the Faculty of Economics, University of Indonesia Library.

Inflation data was gathered from the Indonesian Financial Statistics records (IFS) which are available in the library of Bank Indonesia. Further, GNP data was provided by the Indonesian Central Bureau of Statistics library. The economic growth was computed from real GNP growth from products and services produced, thus to compute the growth, we had to calculate the output of products and services at a fixed price, i.e. the price prevailing in any given year that can be used to assess products and services produced in other years. The value of national income earned in this calculation is called the national income at a fixed price or real national income (Sukirno 2004).

To be included in the final sample, the observation had to meet the following criteria: (1) The companies were manufacturing companies publicly listed on the Indonesian Stock Exchange; (2) The companies produced financial reports from 2000 until

\footnotetext{
${ }^{3}$ http:/ / www.investopedia.com/exam-guide/cfa-level-1/assets/ fixed-asset-disclosures.asp, June 25 2014, 4.05
} pm. 


\section{Table 1. Summary of Sample Selection Procedure}

\begin{tabular}{|c|c|c|}
\hline No. & Data & $\mathbf{N}$ \\
\hline 1. & $\begin{array}{l}\text { Total non-financial listed companies on the Indonesian Stock } \\
\text { Exchange }\end{array}$ & 315 \\
\hline 2. & Complete availability of financial reports from 1999 until 2008 & 146 \\
\hline 3. & Financial reports denominated in Rupiah & 138 \\
\hline 4. & $\begin{array}{l}\text { Complete financial data according to research operational } \\
\text { definition per year }\end{array}$ & 72 \\
\hline 5. & $\begin{array}{l}\text { Total final observations from } 2000 \text { until } 2008 \text { (i.e. } 72 \text { firms x } 9 \\
\text { years) }\end{array}$ & 648 \\
\hline 6. & $\begin{array}{l}\text { Total final observations based on firms' age from } 2003 \text { until } \\
2008 \text { (i.e. } 72 \text { firms x } 6 \text { years) }\end{array}$ & 432 \\
\hline
\end{tabular}

Source: Authors (2010)

2008; (3) Financial statements had to be denominated in Rupiah (Rp). The result of the sample selection is shown in the table below. The total observations comprise of 648 items, covering 73 firms over a 9 year period, but given the availability of data of some firms' ages, the total number observations were reduced to 432, from 72 firms over 6 years.

\section{Empirical Model}

We employed 3 equations to test our hypotheses. The first model was used to test the model without the firms' age variable, but using the moderating variables and industry category as independent variables. The second equation added the firms' age variable without the moderating variables and industry category. While in the third equation, we simultaneously investigated the impact of the firms' age, the moderating variables and the industry category. We used the industry categories as control variables because many previous studies showed that firms' characteristics are very sensitive to the industry category. Based on 9 industry sectorals listed on the Indonesian Stock Exhange, we employed 7 industry categories, i.e.: (1) miscellaneous industries; (2) the trade, service, and investment industries; (3) basic industries and the chemical industry; (4) mining; (5) the consumer products industry; (6) the agricultural industries; (7) the infrastructure, utilities and transportation, plus property and real estate industries. Thus, we used 6 dummy variables and we set the infrastructure, utilities and transportation plus property and real estate industries as the base category. Finally, we also used years as dummy variables to see whether there was an influence from the economic crisis on firms' growth opportunities. Empirical models in this study were formulated as follows:

$$
\begin{aligned}
P B V_{i t}= & \alpha+\beta_{1} R O A_{i t-1}+\beta_{2} \operatorname{SIZE}_{i t-1}+ \\
& \beta_{3} E S T S_{i t-1}+\beta_{4} L E V_{i t-1}+\beta_{5} \Delta G N P_{i t}+ \\
& \beta_{6} I N F_{i t}+\varepsilon_{i t} \ldots \ldots \ldots \ldots \ldots \ldots \ldots \ldots \\
P B V_{i t}= & \alpha+\beta_{1} R O A_{i t-1}+\beta_{2} S I Z E_{i t-1}+ \\
& \beta_{3} E S T S_{i t-1}+\beta_{4} L E V_{i t-1}+\beta_{5} A G E_{i t}+ \\
& \beta_{6} \Delta G N P_{i t}+\beta_{t} I N F_{i t}+\varepsilon_{i t} \ldots \ldots \ldots(2)
\end{aligned}
$$




$$
\begin{aligned}
& P B V_{i t}=\alpha+\beta_{1} R O A_{i t-1}+\beta_{2} S I Z E_{i t-1}+ \\
& \beta_{3} \text { ESTS }_{i t-1}+\beta_{4} L E V_{i t-1}+\beta_{5} A G E_{i t}+ \\
& \beta_{6}{ }^{\prime \prime} G N P_{i t}+\beta_{7} I N F_{i t}+ \\
& \beta_{8} \text { ESTSSIZE }_{i t}+\beta_{9}{\text { ESTS } A G E_{i t}+}+ \\
& \beta_{10} \text { DummyMI }_{i t}+\beta_{11} \text { DummyTSI }_{i t}+ \\
& \beta_{12} \text { Dummy BIC }+\beta_{13} \text { Dummy } A G R+ \\
& \beta_{11} \text { DummyYears }+\varepsilon_{i t}
\end{aligned}
$$

ESTSSIZE $=$ moderating variable, i.e. export sales per total assets multiplied by firm's size

ESTSAGE $=$ moderating variable, i.e. export sales per total assets multiplied by firm's age

Dummy $_{\mathrm{MI}} \quad=$ dummy variable, coded as 1 for miscellaneous industries and zero (0) otherwise

Dummy $_{\text {TSI }}=$ dummy variable, coded as 1 for the trade, services and investment industries and zero (0) otherwise

Dummy $_{\mathrm{BCI}}=$ dummy variable, coded as 1 for the basic and chemical industries and zero (0) otherwise

$$
\begin{aligned}
\text { Dummy }_{\text {MINE }}= & \begin{array}{l}
\text { dummy variable, coded as 1 } \\
\text { for the mining industry and } \\
\text { zero }(0) \text { otherwise }
\end{array} \\
\text { Dummy }_{\text {CPI }}= & \text { dummy variable, coded as 1 } \\
& \text { for the consumer products } \\
& \text { industry and zero }(0) \text { other- } \\
& \text { wise }
\end{aligned}
$$

\section{Empirical Result}

\section{Descriptive Statistics}

Table 2 provides descriptive statistics of the variables based on the Equation 1. The Normality Test showed that the PBV data does not have a normal distribution because Jarque-Bera was larger than 3 , but considering that our total observations are $648(\mathrm{n}>30)$ then the data fulfills the Central Limit Theorem and the data can be assumed to have a normal distribution.

Based on the descriptive statistics output, we found that the average of the PBV was 1.1891, meaning that on average firms had good investment opportunities. The average for the ROA was 0.0469 or 4.69 percent, showing that it was quite low suggesting that firms had a lack of efficiency when using their assets to yield profits. The ESTS had an average value of 0.2805 , which meant that the average of export sales to total sales was 28.05 percent. Thus, on average firms depended on domestic sales for their revenue. Further, the average leverage (LEV) was 
Table 2. Descriptive Statistics

\begin{tabular}{lccccccc}
\hline & PBV & ROA & SIZE & ESTS & LEV & $\Delta$ GNP & INF \\
\hline Mean & 1.1891 & 0.0469 & 11.9502 & 0.2805 & 0.2070 & 0.0533 & 0.0942 \\
Median & 1.0815 & 0.0449 & 11.8626 & 0.1807 & 0.1267 & 0.0543 & 0.0935 \\
Maximum & 2.6036 & 0.9705 & 13.3762 & 0.75989 & 0.6997 & 0.0773 & 0.1710 \\
Minimum & 0.0029 & -0.9722 & 10.6785 & 0.0000 & 0.0000 & 0.0325 & 0.0510 \\
Jarque-Bera & 46.7812 & 7151.472 & 18.1332 & 70.3711 & 85.0522 & 7.2565 & 71.7154 \\
Probability & 0.0000 & 0.0000 & 0.0001 & 0.0000 & 0.0000 & 0.0266 & 0.0000
\end{tabular}

20.70 percent, meaning that the major source of external financing came from equity.

The annual change in GNP ( $\triangle$ GNP) had an average value of 0.0533 or 5.33 percent and the average of the inflation rate (INF) was 0.0942 or 9.42 percent. Generally, the Indonesian government maintains the inflation rate at under 10 percent, thus creating a favorable environment for economic activities.

\section{Statistical Result}

This study used a panel data, consequently we deployed 3 statistical models, i.e. the Common/ Pooled Least Square (PLS), the Fixed Effect Model (FEM) and the Random Effects Model (REM). Table 3 below shows a summary of the results of the estimation coefficients and p-value of the first model.
Before we test the hypothesis, we have to test the best model from the 3 models shown above. ${ }^{4}$ The Chow Test is a statistical test that determines whether the Common/ Pooled Least Square method is used, or alternatively the Fixed Effect Model is employed. The Chow Test result concluded that the most suitable method used for this regression was the Fixed Effect Model. Further, to check if the Random Effects Model was a more appropriate model to use than the Fixed Effect Model, we ran the Hausman Test. The result from this test concluded that the Random Effects Model was the better statistical model because the $\mathrm{p}$-value was not significant. Further observations from this studyi.e. that $N$ (cross section) was greater than the sum of $T$ (time series), showed that generally, the Random Effects Model was more appropriate for this study.

\footnotetext{
${ }^{4}$ We used the Chow Test and Hausman Test to decide the best prediction model. The Chow Test is a test to determine whether PLS or FEM is better. The hypothesis is stated as follow:

H0: Use Common / pooled model Least Square (PLS)

H1: Use the Fixed Effect Model (FEM)

The Hausman Test was used to determine whether the REM or FEM model was better. The hypothesis is stated as follow:

H0: Use Random Effect Model (REM)

H1: Use the Fixed Effect Model (MET)
} 
Table 3. Summary of Statistical Output of First Model

Variabel Dependent: PBV

\begin{tabular}{|c|c|c|c|c|}
\hline Variables & Hypotheses & $\begin{array}{l}\text { Common/Poole } \\
\text { d Least Square }\end{array}$ & $\begin{array}{c}\text { Fixed Effect } \\
\text { Model }\end{array}$ & $\begin{array}{c}\text { Random Effect } \\
\text { Model }\end{array}$ \\
\hline $\mathrm{ROA}$ & $(+)$ & $\begin{array}{c}0.8288^{* * *} \\
(0.0000)\end{array}$ & $\begin{array}{c}0.3533 * * * \\
(0.0003)\end{array}$ & $\begin{array}{c}0.4290 * * * \\
(0.0000)\end{array}$ \\
\hline SIZE & $(+)$ & $\begin{array}{c}0.2447 * * * \\
(0.0000)\end{array}$ & $\begin{array}{c}0.2299 * * \\
(0.0149)\end{array}$ & $\begin{array}{c}0.2188^{* * *} \\
(0.0000)\end{array}$ \\
\hline ESTS & $(-)$ & $\begin{array}{c}-0.3254 * * * \\
(0.0000)\end{array}$ & $\begin{array}{l}-0.0483 \\
(0.6976)\end{array}$ & $\begin{array}{c}-0.2017 * * \\
(0.0326)\end{array}$ \\
\hline LEV & $(-)$ & $\begin{array}{c}-0.5059 * * * \\
(0.0000)\end{array}$ & $\begin{array}{c}-0.1758^{* *} \\
(0.0451)\end{array}$ & $\begin{array}{c}-0.2611 * * * \\
(0.0016)\end{array}$ \\
\hline$\Delta \mathrm{GNP}$ & $(+)$ & $\begin{array}{l}2.4079 * \\
(0.0709)\end{array}$ & $\begin{array}{c}2.6354 * * * \\
(0.0099)\end{array}$ & $\begin{array}{c}2.6246^{* * *} \\
(0.0062)\end{array}$ \\
\hline INF & $(-)$ & $\begin{array}{l}-0.4275 \\
(0.3433)\end{array}$ & $\begin{array}{c}-0.6042^{*} \\
(0.0558)\end{array}$ & $\begin{array}{c}-0.5694^{*} \\
0.0713\end{array}$ \\
\hline \multicolumn{2}{|c|}{$\mathrm{R}^{2}$} & 0.2165 & 0.6605 & 0.0924 \\
\hline \multicolumn{2}{|c|}{ ADJUSTED R ${ }^{2}$} & 0.2092 & 0.6146 & 0.0839 \\
\hline \multicolumn{2}{|c|}{ DURBIN-WATSON } & 0.64180 & 1.2614 & 1.1113 \\
\hline \multicolumn{2}{|c|}{ Prob (F-Stat) } & $0.0000 * * *$ & $0.0000^{* * *}$ & $0.0000^{* * *}$ \\
\hline
\end{tabular}

*** significant at a level of 1 percent

** significant at a level of 5 percent

* significant at a level of 10 percent

Table 4. Chow Test and Hausman Test

Redundant Fixed Effects Tests

Pool: FEM1

Test cross-section fixed effects

\begin{tabular}{lrrc}
\hline \multicolumn{1}{c}{ Effects Test } & \multicolumn{1}{c}{ Statistic } & \multicolumn{1}{c}{ d.f. } & \multicolumn{1}{c}{ Prob. } \\
\hline Cross-section F & 10.4959 & $(71,570)$ & 0.0000 \\
Cross-section Chi-square & 541.8024 & 71 & 0.0000 \\
\hline
\end{tabular}

Correlated Random Effects - Hausman Test

Pool: REM1

Test cross-section random effects

\begin{tabular}{llll}
\hline Cross-section random & 0.000000 & 6 & 1.0000 \\
\hline
\end{tabular}


In general, the regression model output with the Random Effects method can be considered as good. This was indicated by the significant value of Prob (F-statistic), which meant that the model was able to explain the relationship between the Investment Opportunity Set as the dependent variable and the independent variables, namely profitability (ROA), firms' size (SIZE), degree of internationalization (ESTS), leverage (LEV), the annual GNP growth (ÄGNP) and the rate of inflation (INF).

We found that profitability (ROA) had a positive effect on the IOS. Hence, a greater firm profitability also shows a larger possibility of retained earnings for investment purposes (Riahi- Belkaoui and AlNajjar 2001; Riahi-Belkaoui 2002). We also found that the IOS was positively affected by a firm's size (AlNajjar and Riahi-Belkaoui 2001). This finding supports that small companies often face limitations or difficulties in determining their choice and execution of new projects, or difficulties in restructuring existing assets. On the other hand, large companies and more established companies tend to be more active in increasing the value of their investment in various ways, such as product differentiation to create barriers to entry, economies of scale, and patents (Chung and Charoenwong 1991). Thus, large companies tend to dominate market positions in their industry.

Our result showed that the level of internationalization (ESTS) negatively affected the IOS (Hasibuan 2007), so the level of internationalization hampers the investment growth opportunities. This result corroborates the argument that companies face uncertainty and constraints relating to the environment at the international level (Delios and Henisz 2000). International trade regulation in the country where the company is expanding its market will constrain the degree of internationalization of the firm (Hill 2007).

Firm leverage (LEV) negatively affected the IOS (Smith and Watts 1992; Gaver and Gaver 1993; Gul 1999; AlNajjar and RiahiBelkaoui 2001). The interest payments and principal of debt may increase the potential loss of investment because the interest and principal payments can be higher than the return on the investment. In addition, using leverage in the firm's capital structure also limits the investment decisions due to the boundaries in debt covenants (negative covenants), where the lender imposes certain restrictions to ensure repayment of the principal and interest.

Finally, we found that macroeconomic variables influenced the IOS. The annual change of GNP (DGNP) had a positive influence on the IOS, so our result supports the idea that a positive trend in GNP growth will create a favorable climate for investment (Riahi-Belkaoui 2002). Meanwhile, the inflation rate (INF) had a negative influence on the IOS. Therefore, the rate of inflation tends to reduce a company's motivation to develop its economic activities. Investment by a firm is highly dependent on changes in the inflation rate because the inflation rate determines the interest rates and consequently affects the costs of capital for investing firms. High inflation rates will increase interest rates, which in turn will reduce investment (Ratnawati 2007).

Table 5 shows the empirical result of the second equation where the firms' age is added. We obtained the Random Effect Model as the best prediction model and the result showed that: (1) profitability had a positive influence on IOS but was only marginally significant at 10 percent; (2) firms' size and GNP growth had significant effects on the IOS at the 1 percent level; (3) IOS was 
Table 5. Summary of Statistical Output of Second Model

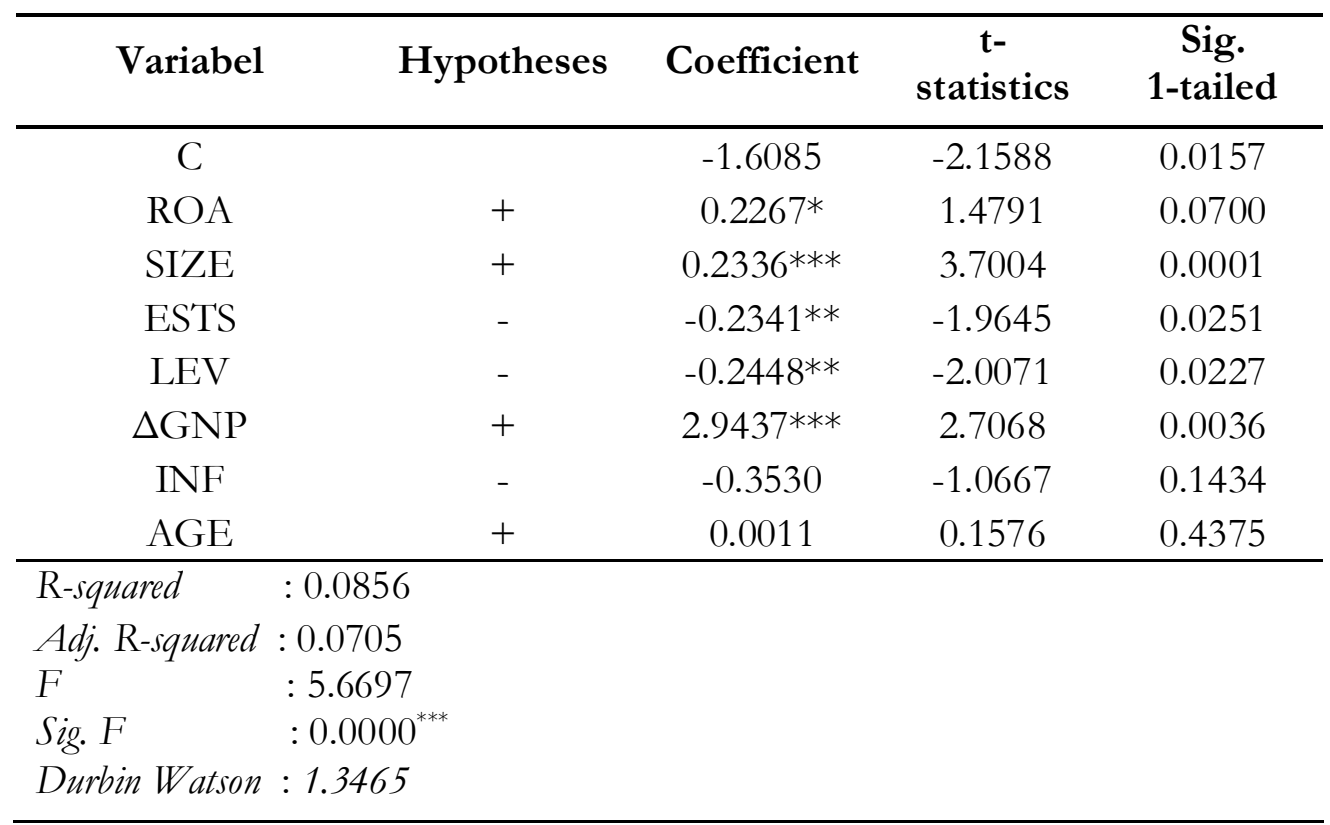

*** significant at 1 percent level

** significant at 5 percent level

* significant at 10 percent level

negatively affected by leverage and significant at 5 percent; (4) we failed to find the influences of inflation and firms' age on the IOS. Therefore, the length of time a firm has existed in the industry does not increase its growth opportunities.

Nevertheless, when we tested the moderating effect of firms' size and firms' age on firms' growth opportunities as shown in Table $6^{5}$, we found that only a firm's age had a moderating effect on the IOS. Thus, this result supports previous studies that find the negative influence of internationalization is weakened by a firm's age. Older fims are assumed: (1) to have a lower risk when conducting foreign expansion plans because these firms tend to have abundant resources and experience (Fernandez and Nieto 2006; Claver et al. 2008; Shrader et al. 2000); (2) the degree of risk aversion to enter a foreign market can be reduced by older firms (Singla and George 2013).

Next, Table 6 also shows that several industries have a lower IOS than other industries, i.e. (a) miscellaneous industries (sig. at 1\%); (b) trade, services and investment (sig. at 1\%); (c) basic and chemical industries (sig. at 1\%); (e) consumer products industries (sig. at $5 \%$ ); and (f) the agricultural industries (sig. at 10\%). Thus, we concluded that firms' IOS was highly determined by the industry category.

We also found that the IOS had a positive relationship on firms' profitability and firms' size, while leverage had a negative impact on IOS. Finally, our results failed to find the relationship between economic conditions and IOS.

${ }^{5}$ We already test OLS, FEM, and REM but FEM cannot be tested because we have a near singular matrix problem. Further, based on OLS and REM, we conclude that OLS is the best prediction model because it has greater Rsquared. 
Table 6. Summary of Statistical Output of Third Model

Variabel Dependent: PBV

\begin{tabular}{|c|c|c|c|c|c|}
\hline Variables & $\begin{array}{c}\text { Common/ } \\
\text { Pooled } \\
\text { Least } \\
\text { Square }\end{array}$ & $\begin{array}{l}\text { Random } \\
\text { Effect } \\
\text { Model }\end{array}$ & Variables & $\begin{array}{c}\text { Common/ } \\
\text { Pooled } \\
\text { Least } \\
\text { Square }\end{array}$ & $\begin{array}{c}\text { Random } \\
\text { Effect } \\
\text { Model }\end{array}$ \\
\hline $\mathrm{ROA}$ & $\begin{array}{c}0.7986 * * * \\
(0.0000)\end{array}$ & $\begin{array}{l}0.2321 * \\
(0.0635)\end{array}$ & Dummy $_{\mathrm{MI}}$ & $\begin{array}{c}-0.3462 * * * \\
(0.0049)\end{array}$ & $\begin{array}{c}-0.3398^{*} \\
(0.0886)\end{array}$ \\
\hline SIZE & $\begin{array}{c}0.3228^{* * *} \\
(0.0000)\end{array}$ & $\begin{array}{l}0.2922 * * * \\
(0.0007)\end{array}$ & Dummy $_{\mathrm{TSI}}$ & $\begin{array}{c}-0.4457 * * * \\
(0.003)\end{array}$ & $\begin{array}{l}-0.3422 \\
(0.1196)\end{array}$ \\
\hline ESTS & $\begin{array}{c}0.1318 \\
(0.4725)\end{array}$ & $\begin{array}{l}1.7910 \\
(0.2340)\end{array}$ & Dummy $_{\mathrm{BCI}}$ & $\begin{array}{c}-0.3592^{* * *} \\
(0.004)\end{array}$ & $\begin{array}{r}-0.3714^{*} \\
(0.0676)\end{array}$ \\
\hline LEV & $\begin{array}{c}-0.5681 * * * \\
(0.0000)\end{array}$ & $\begin{array}{l}-0.1793^{*} \\
(0.0786)\end{array}$ & Dummy $_{\text {MINE }}$ & $\begin{array}{l}-0.1148 \\
(0.2234)\end{array}$ & $\begin{array}{l}-0.1393 \\
(0.3130)\end{array}$ \\
\hline$\Delta \mathrm{GNP}$ & $\begin{array}{l}-0.1198 \\
(0.4803)\end{array}$ & $\begin{array}{l}-0.4129 \\
(0.4004)\end{array}$ & Dummy $_{\mathrm{CPI}}$ & $\begin{array}{c}-0.2823^{* *} \\
(0.0238)\end{array}$ & $\begin{array}{l}-0.2105 \\
(0.2076)\end{array}$ \\
\hline INFL & $\begin{array}{l}-0.1440 \\
(0.3840)\end{array}$ & $\begin{array}{l}-0.2888 \\
(0.1886)\end{array}$ & Dummy $_{\mathrm{AGR}}$ & $\begin{array}{l}-0.2120^{*} \\
(0.0851)\end{array}$ & $\begin{array}{l}-0.1869 \\
(0.2590)\end{array}$ \\
\hline AGE & $\begin{array}{l}-0.0340 \\
(0.0000)\end{array}$ & $\begin{array}{l}-0.0207 \\
(0.0168)\end{array}$ & Dummy $_{\text {years }}$ & $\begin{array}{l}-0.1102 \\
(0.0652)\end{array}$ & $\begin{array}{l}-0.1233 \\
(0.0 .006)\end{array}$ \\
\hline ESTSSIZE & $\begin{array}{l}-0.0930 \\
(0.2769)\end{array}$ & $\begin{array}{l}-0.2315 \\
(0.1279)\end{array}$ & $\begin{array}{l}\mathrm{R}^{2} \\
\text { ADJUSTED R }\end{array}$ & $\begin{array}{l}0.3061 \\
0.2794\end{array}$ & $\begin{array}{l}0.1383 \\
0.1050\end{array}$ \\
\hline ESTSAGE & $\begin{array}{c}0.0714^{* *} \\
(0.0013)\end{array}$ & $\begin{array}{l}0.0759 * * \\
(0.0 .003)\end{array}$ & $\begin{array}{l}\text { DURBIN-WATSON } \\
\text { Prob (F-Stat) }\end{array}$ & $\begin{array}{c}0.7150 \\
0.0000^{* * *}\end{array}$ & $\begin{array}{c}1.3145 \\
0.0000^{* * *}\end{array}$ \\
\hline
\end{tabular}

*** significant at the 1 percent level

** significant at the 5 percent level

* significant at the 10 percent level

\section{Conclusion}

The aim of this study was to examine the impact of internal and external factors on firms' Investment Opportunity Set. When we tested without the industry category and the moderating effects, the result showed that internal factors, i.e. profitability and firm size had a positive impact on the IOS, while firms' leverage and their degree of internationalization had a negative influence on IOS. Fur- ther, the IOS was determined by external factors, i.e. it was positively affected by GNP growth. The implications of this study are: first, as the globalization of business transactions will continue, then a firm must consider the impacts of their exports on their growth opportunity. Second, regulators must create a supporting business environment to provide a higher IOS. Third, investors must carefully select stocks with a high degree of internationalization because that will decrease the 
firms' IOS. Further, the IOS is also determined by favorable macroeconomic conditions. Finally, when we investigated the industry category and the moderating effects of firms' size and age, we concluded that: (1) the negative relationship between the IOS and the degree of internationalization was weakened by the firms' age; (2) certain industries have lower growth than other industries, i.e. miscellaneous industries, trade, ser- vices and investment, basic and chemical industries, consumer products industries; and f) the agricultural industries. The implications from this result are: first, mature firms may conduct higher levels of internalization compared to newer firms because the negative impacts on firms' IOS can be weakened. Second, several industries have a lower potential gain compared to other industries.

\section{References}

Adam, T., and V. K. Goyal. 2007. The Invesment Opportunity Set and It's Proxy Variables. Hong Kong University of Science and Technology.

AlNajjar, F. K., and A. Riahi-Belkaoui. 2001. Empirical validation of a general model of growth opportunities. Managerial Finance 27: 72-90.

Angeline, I. 2007. Analisis pengaruh likuiditas saham, tingkat leverage dan risiko sistematik terhadap return saham (Survey pada perusahaan consumer goods yang terdaftar di BEJ). Thesis. Unpublished. Universitas Indonesia.

Bloodgood, J. M., H. J. Sapienza, and J. G. Almeida. 1996. The internationalization of new high-potential US venture: Antecedents and outcomes. Entrepreneurship Theory and Practice 20 (4): 61 "76.

Bodie, Z., A. Kane, and A. J. Marcus. 2009. Investments ( $8^{\text {th }}$ ed.). McGraw-Hill International Edition.

Chung, K. H., and C. Charoenwong. 1991. Investment options, assets in place, and the risk of stocks. The Financial Management Association International 20: 21-33.

Claver, E., L. Rienda, and D. Quer. 2008. Family firms' risk perception: Empirical evidence on the internationalization process, Journal of Small Business and Enterprise Development 15 (3): 457-471.

Delios, A, and W. J. Henisz. 2000. Japanese firms' investment strategies in emerging economies. Academy of Management Journal 43: 305-323.

Febriana, D. 2004. Analisis faktor-faktor yang mempengaruhi underpricing saham pada perusahaan go public di BEJ (2000-2002). Skripsi. Unpublished Yogyakarta.

Fernandez, Z., and M. J. Nieto. 2006. Impact of ownership on the international involvement of SMEs. Journal of International Business Studies 37 (3):340-351.

Ferri, M. G., and W. H. Jones. 1979. Determinants of financial structure: A new methodological approach. The Joumal of Finance 34: 631-644.

Filatotchev, I., and J. Piesse. 2009. R\&D, internationalization and growth of newly listed firms: European evidence. Journal of International Business Studies 40 (8): 1260-1276.

Francis, B., I. Hasan, L. Song, and M. Waisman. 2013. Corporate governance and investment cash-flow sensitivity: Evidence from Emerging Markets. Emerging Markets Review 15: 57-71. 
Gaver, J. J., and K. M. Gaver. 1993. Additional evidence on the association between investment opportunity set and corporate financing, dividend and compesation policies. Journal of Accounting and Economics 16: 125-160.

Hasibuan, E. 2007. Analisis hubungan profitabilitas, ukuran perusahaan, multinasionalitas, struktur keuangan, dan risiko sistematis dengan investment opportunity set pada perusahaan manufaktur periode 20032005. Skripsi. Unpublished, Universitas Indonesia.

Hill, C. W. L. 2007. International Business. New York: Mc Graw-Hill Inc.

Ho, S. S. M., C. K. Kevin Lam, and H, Sami. 2004. The investment opportunity set, director ownership, and corporate policies: Evidence from an emerging market. Journal of Corporate Finance 10: 383408.

Hope, O., W. Thomas, and D. Vyas. 2011. The cost of pride: Why do firms from developing countries bid higher? Journal of International Business Studies 42: 128-151.

Kallapur, S., and M. A. Trombley. 1999. The association between investment opportunity set proxies and realized growth. Journal of Business Finance and Accounting 26: 505- 519.

Kallapur, S., and M. A. Trombley. 2001. The investment oportunity set: Determinants, consequences and measurement. Managerial Finance 27:3-15.

Keown, A. J., J. D. Martin, J. W. Petty, and D. F. Scott. 2002). Financial Management Principles and Applications ( $9^{\text {th }}$ ed.) Upper Saddle River York, NJ: Prentice Hall.

Kester, W. C. 1984. Today's option for tomorrow's growth. Harvard Business Review, (March/April): 153160.

Kim, W. C., P. Hwang, and P. Burgers. 1989. Global diversification strategy and corporate performance, Strategic Management Journal 10, 45-57.

Lakonishok, J., A. Shleifer, and R. Vishny. 1994. Contrarian investment, extrapolation and risk. Joumal of Finance 49: 1541-1578.

Mason, S. P., and R. C. 1985: The Role of Contingent Claims Analysis in Corporate Finance. In E. Altman, and M. Subrahmanyam, Recents Advances in Corporate Finance (p.: 7-54). Homewood, IL: Richard D. Irwin.

Myers, S. C. 1977. Determinants of corporate borrowing, Journal of Financial Economics 5, 147-175.

OECD. 2012. OECD Reviews of Regulatory Reform Indonesia: Market Openness. www.oecd.org/indonesia/ chap $\% 204 \% 20-\% 20$ market $\% 20$ openness.pdf.

Ratnawati, T. 2007. Pengaruh langsung dan tidak langsung faktor ekstern, kesempatan investasi dan pertumbuhan asets terhadap keputusan pendanaan perusahaan yang terdaftar oada Bursa Efek Jakarta: Studi pada Industri Manufaktur Masa Sebelum Krisis dan Saat Krisis. Jurnal Akuntansi dan Keuangan 9: 65-75.

Riahi-Belkaoui, A. 2002. Profitability, multinationality and the investment opportunity set. Advances in International Accounting 15:1-12.

Sapienza, H. J., E. Autio, G. George, and S. A. Zahra. 2006. A capabilities perspective on the effects of early internationalization on firm survival and growth. Academy of Management Review 31: 914-933.

Savitri, G. K. 2009. Analisis faktor-faktor yang dapat mempengaruhi struktur modal terhadap perubahan nilai perusahaan pada industri properti dan real estate yang terdaftar di Bursa Efek Indonesia tahun 2002-2008. Skripsi. Unpublished. 
Shrader, R. C., M. M. Oviatt, and P. P. McDougall. 2000. How new ventures exploit trade-offs among international risk factors: Lessons for the accelerated internationalization of the 21 st century. The Academy of Management Journal 43(6): 1227-1247.

Singla, C., and R. George. 2013. Internationalization and performance: A contextual analysis of Indian firms. Journal of Business Research 66: 2500-2506.

Smith, C. W. Jr., and R. L. Watts. 1992. The investment opportunity set and corporate financing, dividend, and compensation policies. Journal of Financial Economics 32: 263-292.

Sukirno, S. 2004. Makroekonomi: Teori Pengantar. Jakarta: PT RajaGrafindo Persada.

Sullivan, D. 1994. Measuring the degree of internationalization of a firm. Journal of International Business Studies 25: 325 .

Tumpal, B., and H. Natalia. 2008. Analisa pengaruh kombinasi keunggulan dan keterbatasan perusahaan terhadap set kesempatan investasi (IOS): Studi kasus pada perusahaan manufaktur yang terdaftar di Bursa Efek Indonesia 2007. Skripsi. Unpublished.

Vogt, S. C. 1997. Cash flow and capital spending: Evidence from capital expenditure announcements. Financial Management 26: 44-57.

Wibowo, N., and R. Andiyani. 2008. Analisa variabel struktur aktiva, tingkat pertumbuhan penjualan, ukuran perusahaan, degree of operating leverage, dividend payout ratio, dan profitability yang mempengaruhi struktur keuangan pada perusahaan manufaktur yang terdaftar di Bursa Efek Indonesia. Skripsi. Surabaya.

Xiao, S.S., I. Jeong, J. J. Moon, C. C. Chung, and J. Chung. 2013. Internationalization and performance of firms in China: Moderating effects of governance structure and the degree of centralized control. Joumal of International Management 19: 118-137.

Yildiz, O., O. C. Bozkurt, A. Kalkan, and A. Ayci. 2013. The relationship between technological investment, firm size, firm age, and the growth rate of innovational performance. Procedia-Social and Behavioral Sciences 99: 590-599. 